\title{
The Host Specificities of the z20 and CF2004-6 Strains of an Escherichia coli O4 Serotype
}

\author{
By L. ZUBRZYCKI, SUSAN U. LEVINSON AND D. SIEGEL* \\ Department of Microbiology and Immunology, Temple University School of \\ Medicine, Philadelphia, Pennsylvania I9I40, U.S.A.
}

(Accepted for publication I February 1972)

\begin{abstract}
SUMMARY
We have discovered different host specificities in the Z2O and CF2004-6 strains of a particular Escherichia coli $\mathrm{O}_{4}$ serotype. The host specificities are controlled by a chromosomal locus linked to threonine. They are differentiated on the basis of results from plating efficiencies of phage Ø०4, conjugation, and generalized transduction. The host specificities of E. coli strains KI 2 and CF2004-6 seem to be similar and distinct from that of $\mathrm{z} 20$.
\end{abstract}

\section{INTRODUCTION}

Host-controlled restriction accounts for reduced recombinant frequencies and reduced linkage between markers in matings between strains of Escherichia coli $\mathrm{K} \mathrm{I} 2$ in which donor and recipient differ due to mutation at the host specificity locus (Colson, Glover, Symonds \& Stacey, 1965; Wood, 1966), or the recipient is lysogenic for phage PI (Glover, Schell, Symonds \& Stacey, I963; Boice \& Luria, I963; Pittard, I964; Arber \& Morse, I965). Hostcontrolled restriction also occurs during inter-strain matings between $E$. coli $\mathrm{K} 12$ and $\mathrm{B} / \mathrm{r}$ (Boyer, 1964), and E. coli KI2 and в (Arber \& Morse, I965; Copeland \& Bryson, I966), but not during matings between $E$. coli KI2 and CF2004-6, a specific serotype of E. coli $\mathrm{O}_{4}$ (Zubrzycki \& Levinson, 1969).

It was therefore surprising to discover the host specificities of CF2004-6 and Z20, which constitute a specific intra-strain fertility system (Siegel \& Zubrzycki, I968; Siegel, 1970), are different. The restriction to be described in this paper affects genetic recombination following conjugation and the plating efficiencies of, and generalized transduction by, phage Ø०4.

\section{METHODS}

Media. Penassay broth (antibiotic medium no. 3, Difco, Detroit, Michigan, U.S.A.) and trypticase soy agar (Baltimore Biological Laboratories, Cockeysville, Maryland, U.S.A.) were used for the routine cultivation of bacteria. Eosin methylene blue (EMB) agar (Difco) was used to differentiate lactose and non-lactose fermentors. Semisolid agar for plating phage consisted of $0.7 \%$ agar in trypticase soy broth (Baltimore Biological Laboratories). The composition of the minimal enriched medium and agar and the concentrations of amino acids and streptomycin (used to counter-select donor strains) were described by Zubrzycki \& Levinson (1969).

Bacteria. A recipient, CF2004-6, and a low-frequency donor, Z20 (Siegel \& Zubrzycki, 1968), are strains isolated from a particular Escherichia coli serotype $\mathrm{O}_{4}: \mathrm{K}$ (undetermined) : $\mathrm{H}_{5}$

* Present address: Department of Pharmacology and Physiology, School of Veterinary Medicine, University of Illinois, Urbana, Illinois 61801, U.S.A. 


Strain designation
CF2004-6
CTM-4I
HfrH
LZ-TM-9
MRI9
MRI5 and MR25
O4M2
P4X6
S5 and SIO
Z20

\section{Table I. Strains of Escherichia coli used}

\begin{tabular}{|c|c|}
\hline Strain origin & Pertinent characteristics \\
\hline $\begin{array}{l}\text { E. coli } \mathrm{O}_{4}: \mathrm{K} \text { (undetermined): } \mathrm{H}_{5} \\
\text { CF } 2004-6\end{array}$ & $\begin{array}{l}\text { prototroph, } h s p C F \text {; recipient } \\
\text { trp, ilv; used as indicator strain } \\
\text { for Øo4 }\end{array}$ \\
\hline $\mathrm{K} 12$ & hsp K; Hfr \\
\hline CF2004-6 & trp, leu, arg, his, pro, thr \\
\hline $\mathrm{Z} 20 \times$ CF2004-6 recombinant* & hsp $Z$ \\
\hline $\mathrm{Thr}^{+}$recombinants from $\mathrm{Z} 20 \times \mathrm{LZ}-\mathrm{TM}-9$ & hsp $Z$ \\
\hline P4X6 $\times$ CF $2004-6$ recombinant $\dagger$ & $\operatorname{trp}$, ilv, hsp CF; Hfr \\
\hline $\mathrm{KI} 2$ & $m e t, h s p K ; \mathrm{Hfr}$ \\
\hline $\begin{array}{l}\mathrm{Thr}^{+} \text {recombinants from } \mathrm{HfrH} \times \mathrm{a} t h r \\
\text { strain of MRI5 }\end{array}$ & hsp K \\
\hline E. coli $\mathrm{O}_{4}: \mathrm{K}$ (undetermined) $: \mathrm{H}_{5}$ & $m e t, h s p Z$; low frequency donor \\
\hline
\end{tabular}

(simply referred to as E. coli $\mathrm{O}_{4}$ ). $\mathrm{Z} 20$ does not behave as a donor with recipient strains of E. coli KI 2, С or в (Siegel \& Zubrzycki, I968; Siegel, I970). An Hfr strain of CF2004-6, 04M2, was obtained by selection for a terminal marker, lactose, in a mating between $\mathrm{P} 4 \times 6$ and a lac mutant of CF2004-6 (Zubrzycki \& Levinson, I969). These strains, plus the well-known KI 2 strains, are listed in Table I.

Phage. The generalized transducing phage used in these studies was originally referred to as Øo4-CF (Zubrzycki, Green \& Spaulding, I966), but when modification and restriction of this phage were discovered the hyphenated designation was abbreviated to Ø०4 (Siegel, 1970). The phage is specific for isolates of the serotype of Escherichia coli $\mathrm{O}_{4}$ used in these studies and will not adsorb to E. coli $\mathrm{KI} 2$.

Notations and abbreviations. The abbreviations for genetic markers conform to the recommendations of Demerec, Adelberg, Clark \& Hartman (1966). They are: arg (arginine), his (histidine), ilv (isoleucine), met (methionine), pro (proline), thr (threonine), trp (tryptophan), lac (lactose), leu (leucine), str (streptomycin; $\mathrm{r}$ for resistant, $\mathrm{s}$ for susceptible), hsp (host specificity). The notation to designate the bacterial strain on which phage was grown is that recommended by Arber \& Linn (1969).

Mating experiments. The smooth strains of Escherichia coli do not mate well in broth. Therefore, matings were done on Millipore filters as previously described (Zubrzycki \& Levinson, 1969). Linkage between two markers was determined as described by Zubrzycki \& Levinson (1969). To get a significant number of recombinants when using the lowfrequency donor strain $\mathrm{z} 2 \mathrm{O}$, the donor and recipient must be in contact for a long period of time (Siegel, 1970). This is accomplished simply by mixing equal volumes of young broth cultures containing approximately $\mathrm{I} \times 10^{8}$ donors and $5 \times 10^{8}$ recipients and then spreading $0.2 \mathrm{ml}$ of the mixture on the surface of minimal agar plates. Recombinants were scored after $48 \mathrm{~h}$ of incubation at $37^{\circ} \mathrm{C}$.

Transduction experiments. Overnight broth cultures were centrifuged and resuspended in a one-half volume of saline or buffer (minimal enriched medium, minus glucose). One volume of this $2 \times$ concentrated suspension was mixed with one volume of phage diluted in $\mathrm{I} \%$ tryptone broth (Difco) to a titre of $\mathrm{I} \times \mathrm{IO}^{10} / \mathrm{ml}$. The mixture was incubated at $37^{\circ} \mathrm{C}$ for I $5 \mathrm{~min}$ and then $0.1 \mathrm{ml}$ samples were plated in minimal agar using a pour plating technique. Transductants were scored after $48 \mathrm{~h}$ of incubation at $37^{\circ} \mathrm{C}$. For transduction, cultures lysogenic for $\varnothing_{04}$ were used because the number of transductants is greater than with nonlysogens and over a wide range there is a linear relationship between the number of phage 
Table 2. Efficiency of plating of phage Øo4 grown on Escherichia coli $\mathrm{O}_{4}$ strains with two different host specificities*

\begin{tabular}{|c|c|c|c|c|}
\hline \multirow[b]{2}{*}{ Phage } & \multicolumn{4}{|c|}{ Host strain } \\
\hline & CTM-4I & MRI 9 & MR I 5 & MR25 \\
\hline$\varnothing 04_{4} \cdot \mathrm{CF}$ & {$[\cdot 0$} & 0.0013 & 0.0029 & 0.0029 \\
\hline Ø०4·MR I 9 & 0.0012 & $\mathrm{I} \cdot \mathrm{O}$ & 0.93 & $\mathrm{I} \cdot 05$ \\
\hline$\varnothing 04 \cdot$ MR 15 & 0.0059 & $\mathrm{I} \cdot 04$ & $I \cdot O$ & 0.82 \\
\hline$\emptyset 04 \cdot M R 25$ & 0.0082 & $\mathrm{I} \cdot \mathrm{O}$ & $\mathrm{I} \cdot 2$ & $1 \cdot 0$ \\
\hline
\end{tabular}

* The restriction of Øо4 was not due to differences in adsorption because the kinetics of adsorption were the same in all cases studied. At a bacterial concentration of $3 \times 10^{8} / \mathrm{ml}$ about $75 \%$ of phage is adsorbed in $5 \mathrm{~min}$ and $94 \%$ in $15 \mathrm{~min}$.

used and the number of transductans (L. Zubrzycki, S. V. Levinson \& D. Siegel, unpublished results).

Phage techniques. The techniques for propagating and handling Ø०4 were those previously described (Zubrzycki, Green \& Spaulding, 1966).

Screening for strains with different host specificities. Bacterial isolates were identified as belonging to one or another host specificity type by determining their ability to restrict Ø०4 with different host specificities. To check for modification, plaques of phage which escaped restriction were stabbed with a needle and the phage was suspended in I $\mathrm{ml}$ of broth. The efficiency of plating (e.o.p.) was determined by comparing the titre on permissive and restricting strains.

\section{Restriction and modification of Øం4}

RESULTS

Recombinants from matings between donor z20 and a variety of genetically marked recipient strains of CF2004-6 often yield Øo4 or its tiny plaque-forming variant (Siegel \& Zubrzycki, I 968). In a routine check for lysogeny and immunity to Ø०4 among recombinants, Siegel (I970) discovered four recombinants on which phage Øo4 would plaque at an e.o.p. of about IO $0^{-3}$. The recombinant chosen for further study, MRI9, was found to modify Øo4. The plating efficiencies of stocks of $\varnothing_{04}$ grown on CF2004-6 and MRI9 (Table 2) show that $\varnothing_{04} \cdot \mathrm{CF}$ is restricted and modified by MRI9 to the same extent that Ø04.MRI9 is restricted and modified by CTM-4I, the routine indicator strain for Ø04 grown on CF2004-6.

\section{The hsp Z locus}

The control of modification and restriction observed in MRI9 was presumed to be due to a host specificity locus, $h s p \mathrm{Z}$, transferred from strain Z20. We wanted to incorporate the $h s p Z$ locus into a multiply marked recipient CF2004-6 strain to determine whether the locus was located near $t h r$, as it is in other Escherichia coli strains (Hoekstra \& DeHaan, 1963; Boyer, 1964; Colson et al. I965; Wood, 1966). From a mating experiment between Z20 and LZ-TM-9, two of twenty-five $\mathrm{Thr}^{+}$recombinants tested (MR I 5 and MR25) clearly restricted and modified $\varnothing_{04} \cdot \mathrm{CF}$ but not $\varnothing_{04} \cdot \mathrm{MR}$ I 9 (see Table 2).

If the host specificities of Escherichia coli $\mathrm{KI} 2$ and CF2004- 6 are similar, as reported by Zubrzycki \& Levinson (1969), then replacing the $h s p Z$ locus of MR I 5 or MR25 with the hsp $K$ or $h s p C F$ locus should restore the host specificity originally demonstrated in strains of CF2004-6.

A thr mutant of MRI 5 was mated with $\mathrm{HfrH}, \mathrm{P} 4 \mathrm{X} 6$ and $04 \mathrm{M} 2$ for varying periods of time up to 15 min and selected for $\mathrm{Thr}^{+}$recombinants. The matings were interrupted and limited 
Table 3. Recombinant frequencies for the pro, leu and arg markers after 100 min matings of the Escherichia coli $\mathrm{K} \mathrm{I} 2$ strain $\mathrm{P} 4 \mathrm{X} 6$ and derivatives of E. coli $\mathrm{O}_{4}$

\begin{tabular}{|c|c|c|c|c|}
\hline \multirow[b]{2}{*}{ Donor } & \multirow[b]{2}{*}{ Recipient } & \multicolumn{3}{|c|}{$\%$ Recombinants per input donor } \\
\hline & & pro & leu & $\arg$ \\
\hline \multirow{3}{*}{ P4X6× } & MR I 5 & 0.06 & 0.75 & 0.29 \\
\hline & LZ-TM-9 & $0.2 \mathrm{I}$ & $2 \cdot 0$ & 0.21 \\
\hline & s5 & $0.4 I$ & $4 \cdot 7$ & 0.25 \\
\hline
\end{tabular}

Table 4. The effects of restriction on the linkage of unselected markers from the crosses in Table 3

\begin{tabular}{|c|c|c|c|c|c|c|c|c|c|}
\hline \multirow[b]{2}{*}{ Donor } & \multirow[b]{2}{*}{ Recipient } & \multirow{2}{*}{$\begin{array}{l}\text { Selected markers } \\
\text { Unselected ... }\end{array}$} & \multirow{2}{*}{$\begin{array}{l}\cdots \\
\cdots\end{array}$} & \multicolumn{2}{|c|}{ Pro $^{+}$} & \multicolumn{2}{|c|}{$\mathrm{Leu}^{+}$} & \multicolumn{2}{|c|}{$\mathrm{Arg}^{+}$} \\
\hline & & & & $\mathrm{Leu}^{+}$ & $\operatorname{Arg}^{+}$ & $\mathrm{Pro}^{+}$ & $\mathrm{Arg}^{+}$ & Pro & $\mathrm{Leu}^{+}$ \\
\hline \multirow{3}{*}{$\mathrm{P} 4 \times 6 \times$} & MRI 5 & & & 33 & 2.9 & 1. & 2 . & 0.5 & $9 \cdot I$ \\
\hline & LZ-TM-9 & & & $50 \cdot 0$ & $3 \cdot 4$ & $5 \cdot 4$ & $3 \cdot 7$ & $3 \cdot 2$ & $34 \cdot 0$ \\
\hline & s5 & & & $48 \cdot 0$ & 3.8 & $4 \cdot 2$ & $1 \cdot 6$ & 6.2 & $29 \cdot 0$ \\
\hline
\end{tabular}

to this short period of time to avoid the transfer of large parts of the donor genome to the recipient. Of the $\mathrm{Thr}^{+}$recombinants tested, $\mathrm{I} 7 \%$ ( $12 / 70$ ) from the $\mathrm{HfrH}$ mating, $\mathrm{I} 6 \%$ ( $\left.12 / 72\right)$ from the 04M2 mating and $37 \%$ (19/52) from the P4X6 mating did not restrict $\varnothing_{04} \cdot \mathrm{CF}$ but restricted ØO4.MRI9 with an e.o.p. of approximately $10^{-3}$. To check whether Ø०4.MRI9 which escaped restriction in the $\mathrm{Thr}^{+}$recombinants was now modified, plaques on eleven arbitrarily chosen recombinants were picked and the phage assayed on MR25 with $h s p Z$. They were now restricted by MR25 with an e.o.p. of approximately $10^{-3}$.

The $h s p Z$ locus is probably to the left of the $t h r$ locus as depicted on the Escherichia coli

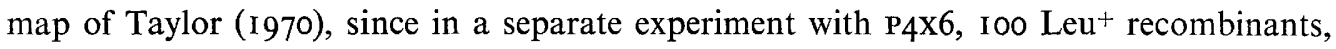
which did not receive the $t h r$ marker, still restricted Øo4 $\cdot \mathrm{CF}$.

To determine whether the different host specificities of Escherichia coli $\mathrm{O}_{4}$ affected genetic recombination during conjugation as they do between other $E$. coli strains, the following crosses were performed. HfrH, P4X6, 04M2, the Hfr donor strain of CF2004-6, were mated with the recipient strains, LZ-TM-9 with $h s p C F$, MR I 5 and MR25 with $h s p Z$ and s5 and sio, two different $\mathrm{Thr}^{+}$recombinants from a P4X6×MRI5 thr mating. These latter recipients also received the $h s p K$ locus as indicated by an e.o.p. of about one for $\emptyset_{04} \cdot \mathrm{CF}$. The results from the mating experiments between the three donor strains and the recipients were essentially the same and the results from matings between P4X6, MR I 5, S5 and LZ-TM-9 are shown in Table 3. The recombinant frequency for the lead marker, pro in the case of $\mathrm{P} 4 \times 6$, is markedly reduced in matings with MRI 5 with $h s p Z$ when compared with the results using LZ-TM-9 with $h s p C F$ and s5 with $h s p K$. The reduction is not as great for the more distal leu marker and disappears for the arg marker which is even further away from the lead marker. The results in Table 4 show that linkage between pro, leu and arg is also reduced in matings with MR I 5 when compared with the results using LS-TM-9 and S5. Figure I shows that there was a delay in appearance of the lead marker in matings with MR I 5 .

We pursued our studies on differentiating the host specificities of Escherichia coli $\mathrm{KI} 2$ and CF2004-6 from those of $\mathrm{Z} 20$ using transduction experiments. As shown in Table 5, the relative transduction frequencies by phage Ø०4.MRI9 into strain LZ-TM-9(Øо4) with $h s p C F$ and strain s5(Øо4) with $h s p K$ were lower than into strain MRI 5(Ø04) with $h s p Z$.

These results, together with the plating efficiencies of $\varnothing_{04}$ and the conjugation experiments, 


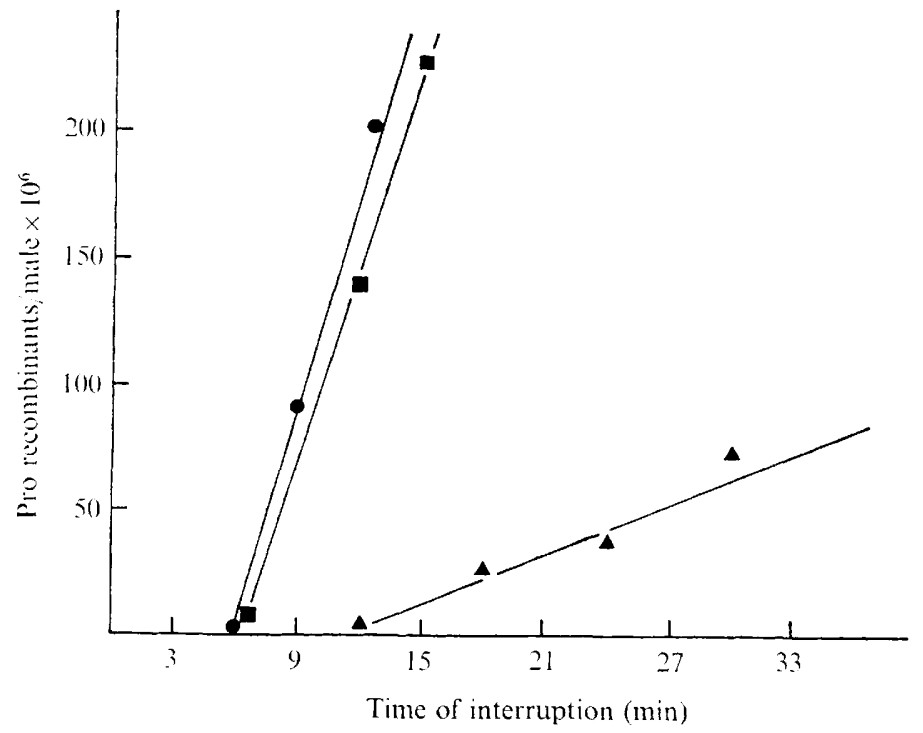

Fig. I. Interrupted mating experiment between P4X6 and s5 (•), LZ-TM-9 (a) and MRI 5 (A), for the early marker pro.

Table 5. Transduction frequencies for the markers listed relative to those by Ø०4. $\mathrm{CF}$ into LZ-TM-9 (Øо4)* which was assigned a value of one

\begin{tabular}{|c|c|c|c|c|c|c|}
\hline Phage & Recipient & $\operatorname{trp}$ & leu & arg & his & pro \\
\hline $\begin{array}{l}\text { Ø०4 } \cdot \text { CF } \\
\text { Ø०4:MR19 }\end{array}$ & \}$\times$ LZ-TM-9 (Øо4) & $\begin{array}{l}1 \cdot 0 \\
0.26\end{array}$ & $\begin{array}{l}I \cdot 0 \\
0 \cdot 5\end{array}$ & $\begin{array}{l}I \cdot O \\
0.5\end{array}$ & $\begin{array}{l}I \cdot 0 \\
0 \cdot 13\end{array}$ & $\begin{array}{l}I \cdot O \\
O \cdot I\end{array}$ \\
\hline $\begin{array}{l}\text { Ø०4·CF } \\
\text { Ø०4·MRI9 }\end{array}$ & \}$\times s_{5}(\varnothing 04)$ & $\begin{array}{l}0.5 \\
0.04 \mathrm{I}\end{array}$ & $\begin{array}{l}0.77 \\
0 \cdot 15\end{array}$ & $\begin{array}{l}0.69 \\
0.23\end{array}$ & $\begin{array}{l}0.58 \\
0.064\end{array}$ & $\begin{array}{l}1 \cdot 3 \\
0.017\end{array}$ \\
\hline $\begin{array}{l}\text { Ø०4 } \cdot \text { CF } \\
\text { Ø०4 } \cdot \text { MR I } 9\end{array}$ & \}$\times \operatorname{MRI} 5(\emptyset 04)$ & $\begin{array}{l}0.054 \\
I \cdot 2\end{array}$ & $\begin{array}{l}0.031 \\
I .6\end{array}$ & $\begin{array}{l}0.056 \\
2 \cdot I\end{array}$ & $\begin{array}{c}<0.0 \mathrm{I} \\
\mathrm{I} \cdot 4\end{array}$ & $\begin{array}{l}0.02 \\
0.12\end{array}$ \\
\hline
\end{tabular}

* Recipients used were lysogenic derivatives (see Methods).

are consistent with our conclusions that the $h s p Z$ and $h s p C F$ loci are closely linked to thr and are allelic to $h s p K$. But the host specificities of $h s p C F$ and $h s p K$ are similar and distinct from that determined by $h s p Z$.

\section{DISCUSSION}

CF2004-6, a recipient, and $\mathrm{z} 20$, a low-frequency donor, are strains isolated from a particular Escherichia coli $\mathrm{O}_{4}$ serotype. They constitute therefore an intra-strain fertility system (Siegel \& Zubrzycki, 1968; Siegel, 1970).

Discovery of host specificity differences in Escherichia coli $\mathrm{O}_{4}$ had to await the chance observation that some recombinants of a Z20 and CF2004-6 mating restricted Ø04. We could not have observed this restriction merely by comparing plating efficiencies of $\varnothing_{04}$ on z2O and CF2004-6 because $\mathrm{z} 2 \mathrm{O}$ is lysogenic for a co-immune small plaque-forming variant of Ø04 (Siegel, 1970). The recombinants used in the studies reported here are not lysogenic for $\varnothing_{04}$ or its small plaque-forming variant. This eliminates the possibility that the small plaque-forming variant of $\varnothing_{04}$ controls the restriction that was observed.

One of the more dramatic results accompanying restriction is the degradation of ${ }^{32} \mathrm{P}$ labelled phage DNA (Arber, 1965). In preliminary work we made repeated attempts to 
detect degradation of ${ }^{32} \mathrm{P}$-labelled $\varnothing_{04}$ DNA during restriction but could not (Siegel, 1970). It may be that our techniques were not sensitive enough to determine the partial degradation of phage DNA that often accompanies restriction (Fukasawa, 1964; Uetake, Toyama \& Hagiwara, 1964; Pizer, Smith, Miovic \& Pylkas, 1968). We became convinced, however, that we were observing host-controlled restriction and modification controlled by the different host specificities of the CF2004-6 and z20 strains of Escherichia coli $\mathrm{O}_{4}$ because: (i) phage $\varnothing_{04}$ which escapes restriction by a second host (be it Z2O or CF2004-6) is modified and, in turn, restricted by the first host; (ii) restriction affects conjugation and transduction; and (iii) the host specificity loci of CF2004-6 and Z20 are closely linked to the thr locus.

These results therefore indicate that members of an intra-strain fertility system may have different host specificities but as Zubrzycki \& Levinson (1969) have shown, the host specificities of an inter-strain fertility system such as that between Escherichia coli KI 2 and the CF2004-6 strain of E. coli $\mathrm{O}_{4}$ can be similar.

Part of this work was taken from a Ph.D. Thesis by Dale Siegel, Temple University, Philadelphia, Pennsylvania (1970), who received support from a predoctoral award and a training grant (GM-oog83) from the U.S. Public Health Service. This investigation was also supported by U.S. Public Health Service research grant AI-0658I. We are grateful to Miss Maria Chillemi and Mrs Eileen Lowe for their technical assistance during part of this work.

\section{REFERENCES}

ARber, W. (1965). Host controlled modification of bacteriophage. Annual Review of Microbiology 19, 365378.

Arber, W. \& Linn, S. (1969). DNA modification and restriction. Annual Review of Biochemistry 38, 467-50o.

ARber, W. \& MORSE, M. L. (1965). Host specificity of DNA produced by Escherichia coli. VI. Effects on bacterial conjugation. Genetics 5I, I37-I48.

BoICE, L. B. \& LURIA, S. E. (1963). Behavior of prophage PI in bacterial matings. I. Transfer of the defective prophage PIdi. Virology 20, I47-I 57.

BOYER, H. (1964). Genetic control of restriction and modification in Escherichia coli. Journal of Bacteriology $88,1652-1660$.

Colson, C., Glover, S. W., Symonds, N. \& Stacey, K. A. (1965). The location of the genes for host-controlled modification and restriction in Escherichia coli $\mathrm{K1}$ 2. Genetics 52, 1043-1050.

COPELAND, J. C. \& Bryson, V. (1966). Restriction in matings of Escherichia coli strain K-I 2 with strain B. Genetics 54, 441-452.

Demerec, M., Adelberg, E. A., Clark, A. J. \& Hartman, P. E. (1966). A proposal for a uniform nomenclature in bacterial genetics. Genetics 54, 6I-76.

FUKASAWA, T. (1964). The course of infection with abnormal bacteriophage $\mathrm{T}_{4}$ containing non-glucosylated DNA on Escherichia coli strains. Journal of Molecular Biology 9, 525-536.

Glover, S. W., Schell, J., Symonds, N. \& Stacey, K. A. (1963). The control of host-induced modification by phage P1. Genetical Research 4, 480-482.

Hoekstra, W. P. M. \& DeHaAn, P. G. (1963). Host controlled modification of phage $\lambda$ in zygotic induction in Escherichia coli в. Antonie van Leeuwenhoek 29, 292-296.

PITTARD, J. (I964). Effect of phage-controlled restriction on genetic linkage in bacterial crosses. Journal of Bacteriology 87, I 256-1 257.

Pizer, L. I., Smith, H. S., Miovic, M. \& Pylkas, L. (1968). Effect of prophage W on the propagation of bacteriophages $\mathrm{T}_{2}$ and $\mathrm{T}_{4}$. Journal of Virology 2, 1339-1 345.

Siegel, D. (1970). An intra-strain fertility system in Escherichia coli $\mathrm{O}_{4}$. Ph.D. Thesis, Temple University. SIEGEL, D. \& ZUBRZYCKI, L. (1968). An intra-strain fertility system in Escherichia coli O4. Bacteriological Proceedings, p. 63.

TAYLOR, A. L. (1970). Current linkage map of Escherichia coli. Bacteriological Reviews 34, 155-175.

Uetake, H., Toyama, S. \& Hagiwara, S. (1964). On the mechanism of host-induced modification: multiplicity activation and thermolabile factor responsible for phage growth restriction. Virology 22, 202-2 I 3. 
WooD, W. B. (1966). Host specificity of DNA produced by Escherichia coli: bacterial mutations affecting the restriction and modification of DNA. Journal of Molecular Biology 16, I 1 8-133.

Zubrzycki, L., Green, J. \& Spaulding, E. H. (1966). A generalized transducing phage for a female Escherichia coli $\mathrm{O}_{4}$. Journal of General Microbiology 45, I I 3-I 22.

ZubrZYCKI, L. \& LeVINSON, S. U. (I969). Genetic heterology between Escherichia coli KI 2 and a smooth strain of E. coli. Journal of General Microbiology 57, 1 1 5-1 23. 